\title{
PEMAHAMAN KONSEP DALAM PEMBELAJARAN MATEMATIKA
}

\author{
Budi Mulyono' ${ }^{1}$ Hapizah $^{2}$ \\ ${ }^{1}$ Universitas Sriwijaya \\ budimulyono.unsri@gmail.com \\ ${ }^{2}$ Universitas Sriwijaya \\ hapizah.unsri@gmail.com
}

\begin{abstract}
ABSTRAK
Artikel ini mendiskusikan tentang apa itu pemahaman konsep dalam pembelajaran matematika serta bagaimana pemahaman konsep dapat terbangun dalam diri seorang siswa. Sebagaimana pada umumnya, yang setidaknya ada dua tipe belajar pada pembelajaran matematika yang pernah kita alami sampai saat ini, yaitu tipe rote learning dan meaningful learning, dimana setiap tipe tersebut memiliki karakteristik yang berbeda satu sama lain. Perbedaan yang paling mendasar dari kedua tipe tersebut adalah pada rote learning lebih menekankan pada hafalan-hafalan yang terstruktur sedangkan pada meaningful learning lebih menekankan pada pemahaman konsep yang dipelajari. Oleh karena itu seorang pengajar perlu mempertimbangkan dengan baik strategi pembelajaran yang tepat sebelum memutuskan mana tipe belajar yang mungkin terbentuk pada anak didiknya, selain itu pengajar juga perlu memperhatikan juga keefektifan dalam pembelajaran agar pemahaman konsep oleh siswa dapat tercapai.
\end{abstract}

Kata Kunci: Pembelajaran Bermakna, Rote Learning, Pemahaman Konsep, Pembelajaran Matematika

\begin{abstract}
This article discusses about what conceptual understanding is in learning of mathematics and how conceptual understanding could be developed in a student's thinking. As we know, generally, at least there are two types of learning that we have already experienced until right now, they are rote learning and meaningful learning, where each type has itself characteristic different from each other. The fundamental difference between the two types of learning is that rote learning emphasizes on memorizing structurally meanwhile meaningful learning focusing on understanding concepts learned. Therefore, teachers should carefully consider suitable strategies of teaching before deciding which types of learning could be developed in students' thinking, and teachers need to pay attention to the effectiveness of teaching and learning in order to help students achieving a conceptual understanding.
\end{abstract}

Keyword: Meaningful Learning, Rote Learning, Conceptual Understanding, Learning of Mathematics

Format Sitasi: Mulyono, B. \& Hapizah. (2018). Pemahaman Kosep dalam Pembelajaran Matematika. KALAMATIKA Jurnal Pendidikan Matematika, 3(2), 103-122.

Penyerahan Naskah: 24 Februari 2017 || Revisi: 19 Juli 2018 || Diterima: 23 Juli 2018 


\section{PENDAHULUAN}

Berdasarkan pengalaman penulis sebagai pengajar di salah satu perguruan tinggi, masih banyaknya mahasiswa baru khususnya semester pertama, yang belum dapat memberikan jawaban yang baik dan benar saat pertama kali ditanya hasil dari bentuk-

bentuk dasar $\frac{0}{0}, \frac{0}{1}$, serta $\frac{1}{0}$. Tidak sedikit dari mahasiswa masih menganggap sama antara istilah tak tentu, tak hingga dan tak terdefinisi, serta tidak mampu memberikan argumentasi yang tepat dari jawaban yang mereka berikan. Namun dari hal tersebut bukan berarti mereka tidak memiliki kemampuan matematika sama sekali, karena paling tidak mereka telah lulus sampai jenjang pendidikan sekolah menengah atas.

Selain hal tersebut, sekitar pertengahan tahun 2014, Indonesia sempat dihebohkan dengan polemik tentang pekerjaan rumah seorang anak sekolah dasar yaitu apakah 4 kali 6 (4 x 6) sama dengan 6 kali 4 (6 x 4), bahkan sampai ada beberapa pakar matematika turut terlibat dalam polemik tersebut. Setiap orang yang mengikuti polemik tersebut mengemukakan keyakinan dan argumentasinya dimana merasa paling benar dengan sudut pandangnya. Ada yang berpendapat bahwa 4 × 6 sama dengan $6 \times 4$, namun ada juga yang berpendapat bahwa $4 \times 6$ tidak sama dengan $6 \times 4$. Menurut pendapat penulis bahwa dua pendapat tersebut jelas bertolak belakang dan hal ini menunjukan bahwa rote learning dan meaningful learning cukup mempengaruhi sudut pandang dari setiap jawaban tesebut.

Pertanyaan yang muncul dari kondisi tersebut adalah apakah pemahaman konsep mereka terhadap apa yang sudah mereka pelajari tidak terbentuk? Serta bagaimanakah pembelajaran matematika yang mereka alami saat di jenjang pendidikan sebelumnya, apakah rote learning ataukah meaningful learning? Bagaimanakah pembelajaran matematika yang sesuai agar pemahaman konsep dapat dicapai oleh siswa?

\section{METODE PENELITIAN}

Mayer dan Witrock (1996) berpendapat bahwa terdapat dua tujuan pembelajaran yang terpenting adalah untuk membentuk kemampuan retention dan kemampuan transfer (dimana jika keduanya tercapai maka mengindikasikan meaningful learning). Retention merupakan kemampuan untuk mengingat dalam jangka waktu yang cukup lama untuk materi yang dipelajari. Sedangkan transfer merupakan kemampuan untuk menggunakan apa yang telah dipelajari untuk menyelesaikan permasalahan baru, menjawab soal baru, atau memfasilitasi untuk mempelajari hal yang baru. Oleh karena itu seorang pengajar perlu 
mempertimbangkan strategi pembelajaran yang tepat agar tercipta efektifitas belajar dan siswa mencapai dua kemampuan tersebut.

Menurut Mayer (2002) terdapat tiga skenario belajar yaitu no learning, rote learning, dan meaningful learning. Mayer mengilustrasikan ada tiga orang pelajar yaitu Amy, Becky, dan Carla membaca sebuah buku yang sama kemudian diberikan tes dengan materi yang terdapat di buku tersebut.

Skenario Pertama: Amy diminta membaca materi pelajaran di sebuah bab, dan dia hanya membaca sepintas (skimming) materi tersebut. Kemudian dia diminta menjawab pertanyaan tentang yang ada pada bab tersebut (retention test). Ternyata, Amy hanya mampu menuliskan sedikit kata-kata kunci dan hal penting pada bab tersebut, meskipun semua jawaban dari pertanyaan tersebut sebenarnya tertulis lengkap di bab tersebut. Selanjutnya ketika Amy diminta untuk informasi yang didapatnya dari bacaannya untuk menjawab suatu permasalahan (transfer test), dia tidak mampu memberikan jawabannya. Dalam hal ini Amy tidak memiliki serta tidak mampu menggunakan pengetahuan yang relevan. Dengan kata lain Amy tidak cukup baik membaca materi yang ada di bab tersebut. Mayer mengkategorikan skenario Amy ini sebagai no learning.

Skenario Kedua: Becky membaca bab yang sama, namun dia membaca dengan sangat hati-hati untuk meyakinkan bahwa dia membaca setiap kata-katanya. Becky menghafal semua kata kunci dan ha-hal yang penting pada bab tersebut. Ketika Becky diminta untuk mengingat materi (retention test) yang ada di bab tersebut, ternyata dia mampu mengingat hampir seluruh kata kunci dan hal-hal penting di bab tersebut. Namun, ketika Becky diminta untuk menjawab soal essay yang membutuhkan kemampuan mendiagnosa masalah (transfer test), dia tidak mampu menjawab soal tersebut. Dalam hal ini Becky memiliki pengetahuan yang relevan namun Becky tidak mampu menggunakannya dalam situasi baru. Dengan kata lain Becky mampu menghafal informasi-informasi yang relevan namun dia tidak memahaminya sehingga Becky tidak dapat menggunakan informasi tersebut. Menurut Mayer hasil belajar (learning outcome) dari skenario Becky ini dikategorikan sebagai rote learning.

Skenario Ketiga: Carla membaca bab yang sama, namun Carla membaca sangat hati-hati dan berusaha untuk memahami setiap kata yang dibacanya. Ketika Carla ditanya tentang bab yang telah dibacanya (retention test), sama seperti Becky, Carla mampu mengingat hampir semua kata kunci dan hal-hal penting di bab tersebut. Carla pun mampu 
memberikan banyak jawaban-jawaban yang mungkin dari suatu permasalahan di soal essay. Dalam skenario ini, Carla tidak hanya memiliki pengetahuan yang relevan, namun juga dapat mengunakannya untuk menyelesaikan masalah serta memahami konsep baru. Dengan kata lain Carla mampu mentransfer pengetahuanya ke permasalahan dan situasi belajar yang baru. Mayer mengatakan bahwa Becky menguasai dengan baik informasi yang relevan dan juga memahaminya. Skenario ini disebut oleh Mayer sebagai meaningful learning.

Dari ketiga skenario belajar yang diilustrasikan oleh Mayer, terlihat bahwa upaya belajar dan proses kognitif yang dilakukan oleh ketiga siswa tersebut mempengaruhi makna dari hasil belajar yang dicapainya. Seperti yang dikatakan oleh Mayer bahwa meaningful learning muncul saat siswa membangun pengetahuan dan proses kognitif yang dibutuhkan untuk mampu dengan baik menyelesaikan suatu permasalahan. Mayer juga berpendapat bahwa fokus dari meaningful learning adalah konsisten dengan pandangan tentang belajar sebagai konstruksi pengetahuan dimana siswa berupaya memahami dan menerima pengalaman-pengalaman belajar mereka.

Tidak berbeda jauh dengan pendapat Mayer sebelumnya, menurut Korb (2011), terdapat dua kondisi untuk belajar efektif, yaitu: retain dan transfer. Adapun makna dari retain adalah mengingat apa yang dipelajari pada masa akan datang, sedangkan transfer bermakna menggunakan apa yang dipelajari untuk mengarahkan pikiran dan sikap dalam suatu situasi yang baru. Sedangkan menurut Korb (2011), perbandingan hasil belajar antara meaningful learning dan rote learning dapat dilihat pada tabel 1.

Tabel 1. Perbandingan meaningful learning dan rote Learning

\begin{tabular}{lc}
\hline \multicolumn{1}{c}{ Meaningful Learning } & \multicolumn{1}{c}{ Rote Learning } \\
\hline Concept is fully understood by student & Verbatim memorization of new information \\
$\begin{array}{l}\text { New information is related to what students already know } \\
\text { (prior knowledge) }\end{array}$ & No connection between new and previous knowledge \\
\hline
\end{tabular}

Berdasarkan Tabel 1 dapat dikatakan bahwa rote learning pencapaiannya hanya retention informasi-informasi baru, sedangkan pada meaningful learning pencapaiannya tidak hanya retention namun juga transfer dan bahkan pencapaian hafalannya (retention) lebih baik daripada rote learning.

Sedangkan menurut Korb (2011) perbandingan antara pembelajaran untuk meaningful learning dengan rote learning seperti pada tabel 2. Perbedaan mendasar dari kedua tipe belajar tersebut, dimana pada pembelajaran untuk meaningful learning lebih menekankan pada keterkaitan materi dengan pengalaman sehari-sehari siswa dan selalu menghubungkan dengan pengetahuan sebelumnya. Sedangkan pada pembelajaran untuk 
rote learning lebih menekankan pada hafalan-hafalan prosedural yang tidak memerlukan keterhubungannya dengan pengalaman siswa serta tidak mengintegrasikan dengan pengetahuan siswa sebelumnya.

Tabel 2. Perbandingan pembelajaran meaningful learning dan rote learning

\begin{tabular}{cc}
\hline Meaningful & Rote \\
\hline Relate information to everyday experiences & $\begin{array}{c}\text { Present definitions, formulas, and new information without } \\
\text { explaining relationship with students' experiences } \\
\text { Deliberate effort to link new knowledge with prior knowledge } \\
\text { Random presentation of new knowledge into memory with no } \\
\text { effort to integrate new knowledge with prior knowledge }\end{array}$ \\
\hline
\end{tabular}

Korb (2011) memberikan beberapa saran dalam pengajaran untuk meaningful learning sebaiknya melakukan beberapa hal berikut:

1. Gunakan analogi.

2. Gunakan cerita untuk mendemonstrasikan konsep.

3. Tanyakan siswa tentang pengalaman mereka yang berhubungan dengan materi pelajaran.

4. Tanyakan ke siswa pertanyaan sedikit lebih tinggi dari apa yang telah diajarkan secara langsung untuk menguji pemahaman mereka.

Masih menurut Kobr (2011) agar meaningful learning terjadi sebaiknya kondisi-kondisi terbentuk:

1. Siswa mengerjakan tugas-tugas dengan tujuan terlibat dalam meaningful learning; karena jika siswa hanya ingin menghafal saja maka meaningful learning tidak akan terjadi.

Aplikasi: Guru harus mengajarkan siswa cara terlibat dalam meaningful learning dan menanamkan pemahaman tentang manfaat dari meaningful learning kepada siswa.

2. Siswa harus memiliki latarbelakang pengetahuan yang relevan dengan materi baru yang akan dipelajari.

Aplikasi: Guru harus yakin bahwa siswanya telah memiliki pengetahuan dasar yang relevan untuk mempelajari topik yang baru.

3. Guru harus mendesain pembelajaran yang meaningful

Aplikasi: Pembelajaran harus dipersiapkan secara baik dan dilaksanakan secara jelas, dan bermakna yang berhubungan dengan kehidupan siswa serta pengetahuan sebelumnya, serta terorganisasi dengan baik. 
Dari uraian mengenai rote learning dan meaningful learning tersebut menunjukan bahwa seorang pengajar berperan penting dalam membentuk hasil belajar siswanya. Perbedaan mendasar dari kedua tipe belajar tersebut adalah pada upaya dan proses kognitif yang dilakukan oleh siswa, dimana rote learning lebih pada hasil hafalan saja namun tidak sampai pada tahapan penggunaan pengetahuan yang dihafal. Sedangkan meaningful learning mencakup tahapan hafalan dan penggunaan pengetahuan yang dipelajari sehingga tahapan pemahaman konsep dapat dicapai siswa.

\section{HASIL DAN PEMBAHASAN}

Pemahaman konsep merupakan sebuah prase yang sering dipakai dalam literatur pendidikan, meskipun belum secara menyeluruh dipahami oleh guru-guru. Pada dua puluh tahun terakhir, pengajar matematika sering membedakan pemahaman konsep (conceptual understanding) dan pengetahuan procedural (procedural knowledge). Titik awal yang bagus untuk kita memahami apa itu pemahaman konsep adalah dengan mereview The Learning Principle dari National Council of Teachers of Mathematics (NCTM) yaitu Principles and Standards for School Mathematics tahun 2000. Sebagaimana satu dari enam prinsip tersebut menyatakan bahwa: siswa harus mempelajari matematika dengan pemahaman, secara aktif membangun pengetahuan baru dari pengalaman dan pengetahuan sebelumnya.

Selama beberapa dekake, penekanan utama di matematika sekolah pada pengetahuan procedural (procedural knowedge), atau yang sekarang dikenal sebagai keahlian prosedural (procedural fluency). Dimana pembelajaran dengan hafalan (rote learning) merupakan aturan atau patokan, dengan sedikit perhatian pada pemahaman terhadapa konsep-konsep matematika. Pembelajaran dengan hafalan bukanlah jawaban dalam matematika, khususnya saat siswa tidak memahami matematika.

Dalam beberapa tahun terakhir, upaya-upaya besar telah dibuat untuk fokus pada apa yang diperlukan atau dibutuhkan siswa untuk belajar matematika, apa cara untuk siswa agar mampu menunjukkan keterampilan atau keahlian secara matematika (mathematically proficient). National Research Council (2001) menyatakan lima struktur (strands) yang meliputi diantaranya adalah pemahaman konsep (conceptual understanding).

Struktur-struktur tersebut saling berkaitan erat dan meliputi hal-hal yang disarankan oleh NCTM (2000) dalam prinsip pembelajarannya (Learning Principle). Untuk berketrampilan dan ahli secara matematika, seorang siswa harus memiliki:

1. Pemahaman Konsep (Conceptual Understanding): pemahaman terhadap konsepkonsep matematika, operasi-operasi, dan relasi-relasi. 
2. Ketrampilan atau keahlian prosedural (Procedural Fluency): ketrampilan atau kelancaran dalam menggunakan prosedur secara fleksibel, secara akurat, secara efisien, dan secara tepat atau sesuai.

3. Kemampuan strategi (Strategic Competence): kemampuan untuk memformulasi, menyatakan pendapat atau jawaban, dan menyelesaikan permasalahan-permasalahan matematika.

4. Argumentasi yang adaptif (Adaptive Reasoning): kemampuan atau kapasitas untuk pemikiran yang logis, untuk refleksi, untuk penjelasan, dan untuk justifikasi.

5. Pemikiran atau pandangan produktif (Productive Disposition): kecenderungan atau tendensi yang terbiasa untuk melihat matematika sebagai suatu yang masuk akal, bermanfaat, dan bernilai, berbarengan dengan sebuah keyakinan (belief) dalam ketekunan (diligence) serta kemampuan seseorang untuk menghasilkan sesuatu dampak yang diinginkan (efficacy).

Sebagaimana kita memulai untuk lebih membangun ide tentang pemahaman konsep (conceptual understanding) dan memberikan contoh-contoh dari makna pemahaman konsep tersebut, perlu dicatat bahwa keseimbangan haruslah terjaga. Kelima struktur (strands) tersebut krusial bagi siswa untuk memahami dan menggunakan matematika. Conceptual Understanding $(\mathrm{CU})$ atau pemahaman konsep memungkinkan siswa untuk menggunakan dan menyesuaikan beberapa ide matematika yang dikuasai ke situasi-situasi yang baru.

National Center for Education Statistics (2003) menjelaskan secara detail dan secara spesifik apa itu kemampuan matematis (mathematical abilities) yang diukur dengan program tes secara nasional (the nationwide testing program). Kemampuan-kemampuan tersebut (mathematical abilities) meliputi pemahaman konsep (CU), pengetahuan procedural (Procedural Knowledge), dan pemecahan masalah (Problem Solving). Terdapat tumpang tindih (overlap) yang signifikan dalam definisi pemahaman konsep (CU) yang diberikan oleh kedua lembaga yaitu National Research Council dan NCTM.

Siswa menunjukkan atau mendemonstrasikan pemahaman konsep dalam matematika saat mereka memberikan bukti (provide evidence) bahwa mereka dapat:

1. mengenali (recognize), menandai (label), dan menghasilkan atau memberikan (generate) contoh-contoh dari konsep-konsep;

2. menggunakan (use) dan menghubungkan (interrelate) model-model, diagram-diagram, manipulasi-manipulasi, dan representasi-representasi beragam dari konsep-konsep; 
3. mengidentifikasi (identify) dan mengaplikasikan (apply) prinsip-prinsip;

4. mengetahui (know) dan mengaplikasi (apply) fakta-fakta dan definisi-definisi;

5. membandingkan (compare), membedakan (contrast), dan mengintergasikan (integrate) konsep-konsep dan prinsip-prinsip yang berkaitan;

6. mengenali (recognize), mengintepretasi (interpret), dan mengaplikasikan (apply) tanda-tanda, simbol-simbol, istilah-istilah (terms) yang digunakan untuk merepresentasikan konsep-konsep.

Pemahaman konsep (CU) memanifestasikan atau merefleksikan (reflects) suatu kemampuan siswa untuk memberikan penjelasan serta alasan (to reason) dalam konteks atau situasi (in-settings) yang melibatkan pengaplikasian yang hati-hati dan terukur dari definisidefinisi konsep, relasi-relasi, atau representasi-representasinya.

Untuk membantu siswa kita dalam mencapai pemahaman konsep (CU) matematika yang mereka pelajari membutuhkan suatu keseriusan kerja yang penuh, yaitu menggunakan sumber daya kelas kita (buku teks, bahan-bahan belajar tambahan, dan alat-alat peraga pembelajaran) meskipun untuk penggunaan hal-hal tersebut kemungkinan kita tidak atau belum dilatih.

Berikut beberapa contoh yang memberikan kejelasan tanpa ambiguitas tentang apa itu pemahaman konsep (CU) yang mungkin terjadi atau terlibat di ruang kelas.

1. Untuk tingkat 3 sampai tingkat 5, penggunaan nol dengan permasalahan letak nilai adalah hal yang sederhana, namun penting (critical) untuk pemahaman. "Berapakah hasil dari $20+70$ ?" Seorang siswa yang dapat secara efektif menjelaskan masalah matematika itu mungkin akan mengatakan, "20 adalah 2 puluhan dan 70 adalah 7 puluhan. Dengan demikian, 2 puluhan dan 7 puluhan adalah 9 puluhan. 9 puluhan sama dengan 90."

2. Pada tingkat 5 sampai 6, operasi-operasi dengan decimal-desimal merupakan topik yang umum. "Berapakah hasil dari 6,345 x 5,28?" Seorang siswa memiliki pemahaman konsep (CU) matematika saat siswa tersebut dapat menjelaskan bahwa 335,016 tidak mungkin menjadi hasil perkalian yang benar karena satu faktor lebih besar dari 6 dan kurang dari 7, sedangkan faktor keduanya lebih besar dari 5 dan kurang dari 6; oleh karena itu hasil kalinya pasti diantara 30 dan 42.

Berikut hal-hal yang dapat dilakukan guru dalam membantu siswa membangun pemahaman konsep dalam pembelajaran matematika: 
1. Membuat siswa untuk menggunakan alat peraga untuk memodelkan konsep-konsep, dan kemudian mengungkapkan hasil-hasil mereka, membantu siswa dalam memahami ide-ide abstrak.

2. Membuat siswa untuk menunjukkan representasi-representasi berbeda dari suatu situasi matematika yang sama merupakan hal penting untuk pemahaman konsep terbentuk.

3. Membuat siswa untuk menggunakan pengetahuan yang dimiliki sebelumnya untuk membangun pengetahuan baru, dan untuk menggunakan pengetahuan barunya untuk menyelesaikan permasalahan-permasalahan dalam situasi-situasi yang tidak dikenal sebelumnya merupakan hal penting juga untuk pemahaman konsep (CU).

4. Membuat siswa untuk melihat hubungan-hubungan antara matematika yang mereka sedang pelajari dan apa yang mereka telah pelajari juga membantu siswa dalam pemahaman konsep (CU).

Sebagaimana yang dinyatakan oleh National Research Council tahun 2001, pada saat siswa memiliki pemahaman konsep (CU) matematika yang mereka telah pelajari, mereka "menghindari banyaknya kesalahan-kesalahan hal yang penting dan mendasar (critical errors) dalam menyelesaikan masalah-masalah, khususnya kesalahan-kesalahan yang berkaitan dengan hitungan bilangan (errors of magnitude)."

NCTM memberikan sebuah konklusi yang sangat baik untuk pembahasan pemahaman konsep (CU), yaitu: "Pembelajaran dengan pemahaman merupakan hal yang mendasar dan penting (essential) untuk membuat siswa mampu untuk menyelesaikan bentuk-bentuk baru permasalahan-permasalahan yang mereka akan hadapi secara kebutuhan di masa depan. “"

Guru-guru matematika harus menciptakan kesempatan-kesempatan (opportunities) bagi siswa untuk mengomunikasikan topik-topik pemahaman konsep mereka. Hal ini dapat melibatkan struktur-struktur instruksi pembelajaran yang membutuhkan sebuah perubahan dalam teknik-teknik pengajaran (pedagogical techniques). Ide-ide atau gagasan-gagasan untuk mendukung siswa dalam membangun pemahaman konsep (CU) matematika siswa haruslah ditunjang sumber daya bagi guru-guru. 


\section{Bagaimana Mengajar Matematika Secara Konsep?}

Instruksi matematika pada umumnya secara historis berfokus pada prosedurprosedur, fakta-fakta, dan algoritma-algoritma. Karena hal tersebut, instruksi matematika, dalam prinsipnya, menjadi langkah-langkah pembelajaran dalam hal aritmatika dan dalam hal efisiensi. Saat terdapat perubahan-perubahan menjanjikan yang muncul dalam instruksiinstruksi matematika, kita tetap perlu membantu para guru dan siswa membangun sesuatu pemahaman matematika yang lebih terhadap matematika. Isu ini menjelaskan bagaimana para pengajar dapat mengubah cara dari membantu siswa menghafal formula-formula ke cara memfasilitasi pemahaman yang mendalam terhadap konsep-konsep matematika.

Hal ini sepenuhnya memungkinkan bagi siswa untuk menghafal fakta-fakta matematika dan memanipulasi angka-angka tanpa memiliki suatu pengetahuan mendalam tentang konsep-konsep atau proses-proses yang dilibatkan. Ingatan terhadap formula-formula dan penguasaan terhadap komputasi tidaklah sama dengan pengetahuan yang benar terhadap konsep-konsep dan ide-ide matematika. Hasil dari praktik kedua hal tersebut adalah pencapaian yang rendah dalam matematika. Menurut National Center for Education Statistics (2013), hanya $42 \%$ dari siswa tingkat 4 dan hanya 35\% dari siswa tingkat 8 yang berada atau di atas level mahir (proficient level) dalam matematika untuk nilai-nilai mereka. Begitu juga, hanya 44\% dari lulusan sekolah tingkat lanjut tahun 2013 di Amerika Serikat yang siap untuk matematika tingkat perguruan tinggi. Jika kita ingin membantu siswa membangun ketrampilan matematika yang akan membuat mereka bisa memasuki bidang STEM (science, technology, engineering, and mathematics) dan membuat tetap kompetitif secara global, kita perlu mengubah beberapa strategi-strategi instruksional.

Pengajaran Matematika secara konsep menurut Molina (2014) sebaiknya melakukan hal-hal berikut:

1. Gunakan bahasa instruksional secara hati-hati.

2. Tekankan pengajaran pada konsep dibandingkan algoritma dan jalan-jalan singkat.

3. Hindari angka-angka yang gundul (naked number).

4. Bantu siswa membuat koneksi antar konsep.

Guru matematika dan pembimbing instruksional sebaiknya memandang serta mempertimbangkan langkah-langkah tersebut dalam membangun pemahaman yang mendalam terhadap konspe-konsep matematika, yang seharusnya meningkatkan kualitas instruksi dan juga pembelajaran siswa.

Berikut uraian ataupun deskripsi dari hal-hal yang harus dilakukan guru menurut Molina (2014): 


\section{Gunakan Bahasa Instruksi Dengan Hati-Hati}

Telah lama istilah-istilah umum menjadi melekat pada instruksi-instruksi matematika; istilah-istilah tersebut sering memiliki definisi atau pengertian berbeda dalam standar bahasa yang ada dengan yang di matematika. Hal ini dapat sangat membingungkan atau menyebabkan salah arah serta kurang akurat.

Sebagai contoh dalam bahasa Inggris, seorang guru bisa jadi menuliskan pecahan (fraction) $\frac{9}{12}$ dan berkata kepada siswa untuk memperkecil atau mereduksi (reduce) pecahan tersebut. Siswa diharapkan untuk mengikuti proses komputasi atau perhitungan dan akhirnya mencapai hasil $\frac{3}{4}$. Penggunaan istilah mereduksi (reduce) yang kurang hati-hati dalam matematika mengarahkan pada kontradiksi makna kata standar yang sebenarnya, yaitu "membuat menjadi kecil" (to make smaller). Apakah merupakan suatu mengherankan bahwa beberapa siswa menjadi bingung dan berpikir bahwa $\frac{3}{4}$ lebih kecil dari $\frac{9}{12}$ ? Dimana akhirnya memang 3 dan 4 memang lebih kecil dari 9 dan 12. Pada saat kita masih sekolah dasar guru matematika mengalami kesulitan untuk meyakinkan kita bahwa kedua pecahan tersebut adalah sama. Dimana pada akhirnya siswa menerima begitu saja apa yang guru katakan dengan tanpa suatu pemahaman yang jelas. Beruntungnya, kurikulum baru dan buku teks mendeskripsikan proses perubahan $\frac{9}{4}$ menjadi $\frac{3}{4}$ sebagai proses penyederhanaan (simplying) dibandingkan sebagai proses mereduksi atau memperkecil (reducing).

Matematika merupakan suatu displin yang akurat, dan guru terkadang tidak menyadari bahwa kekeliruan kecil dalam berbahasa dapat menyebabkan kontennya menjadi salah. Ambil sebagai contoh definisi dari sebuah eksponen (pangkat). Beberapa guru beralih dari definisi pangkat atau eksponen yang benar yaitu "pangkat mengindikasikan berapa kali bilangan pokok muncul sebagai faktor", dan guru tersebut lebih menginformasikan ke siswa bahwa pangkat menyatakan berapa kali bilangan pokok dikalikan. Penguraian secara benar, untuk ekspresi $7^{3}=7.7 .7$, perhatikan bahwa hanya ada dua perkalian, bukannya tiga perkalian. Berdasarkan definisi yang kurang hati-hati, penguraian $7^{3}=7.7 .7 .7$ yang jelas adalah salah. Kekeliruan kecil tersebut memang tidak diinginkan, namun hasilnya merupakan definisi yang salah secara matematika yang diajarkan secara tidak disengaja kepada siswa dan berpengaruh pada proses belajar kedepannya. 
Kekeliruan dan kesalahan tersebut tidak terbatas pada bahasa, dan dapat juga disebabkan karena pengabaian atau tidak perhatiannya dibandingkan ketidakhati-hatian. Tanda " - " merupakan contoh yang sangat baik. Penekanannya pada interpretasi-interpretasi seperti min, pengurangan, atau negatif. Banyak yang dari kita yang tidak diajarkan tanda tersebut dalam suatu konteks tertentu, yang seharusnya diinterpretasikan sebagai "lawan dari”. Interpretasi ini sangat jarang digunakan namun sangat penting secara argumentasi. Perhatikan ekspresi " $-y$ “. Sebuah kesalahan umum adalah cara menyebutkan ekspresi tersebut sebagai "negatif $y$ ". penyebutan yang problematik ini mengarahkan siswa pada kesimpulan yang salah bahwa ekpresi tersebut merepresentasikan sebuah bilangan negatif. Bagaimana jika $y=-4$ ? Dalam kasus ini, nilai dari $-y$ adalah $-(-4)$, atau positif 4 . Kesulitan dalam suatu ekspresi $-(-4)$ adalah setiap tanda negatif harus ditranslasikan dengan kata-kata yang berbeda. Tanda negatif yang diluar kurung seharusnya ditranslasikan sebagai "lawan dari", sedangkan tanda yang didalam ditranslasikan sebagai "negatif", dimana interpretasi lengkapnya adalah "lawan dari negatif 4". Interpretasi ini membuat siswa dapat memahami dengan lebih baik kenapa hasil akhirnya adalah positip 4. Selain itu, interpretasi "lawan dari" tidak hanya menyederhanakan dan memperdalam pemahaman konten namun juga membantu langkah-langkah matematika dengan mengeliminasi aturanaturan yang tidak akurat seperti "dua negatif menjadi positif", sebuah aturan yang juga merupakan contoh lain dari bagaimana langkah-langkah matematika terkadang jauh lebih kompleks daripada yang dibutuhkan.

Contoh-contoh di atas telah mengilustrasikan beberapa instruksi bahwa bahasa yang kurang hati-hati dapat menyebabkan kebingungan dalam langkah-langkah matematika. Jika seorang siswa berusaha dengan kesulitan untuk memahami sebuah konsep matematika, perlu diperhatikan serta dipertimbangkan apakah penggunaan bahasa merupakan penyebab utama dalam kesulitan. Dengan memfokuskan pada bahasa matematika, guru dapat meningkatkan baik konten maupun instruksi, meyakinkan bahwa siswa mencapai sebuah pemahaman mendalam terhadap matematika.

2. Tekankan pengajaran pada konsep dibandingkan algoritma dan jalan-jalan singkat.

Sebuah tradisi yang secara mendalam mengakar dalam instruksi matematika adalah fokus pada algoritma dan jalan singkat tanpa diawali meyakinkan pemahaman konsep. Algoritma dan jalan singkat bukanlah hal yang jelek secara esensialnya; kunci menggunakan hal-hal tersebut untuk membantu daripada menghambat pemahaman terletak dalam urutan 
dari kejadian-kejadian yang muncul dalam proses belajar konsep-konsep matematika. Langkah-langkah atau isntruksi matematika haruslah pertama-tama meyakinkan bahwa pemahaman konsep yang dimiliki siswa tertanam secara mendalam. Saat siswa telah menguasai secara benar sebuah konsep, mereka akan dapat menunjukkan semua langkahlangkah detail dalam sebuah proses, mampu menjelaskan kenapa langkah-langkah tersebut muncul, serta bisa mengoneksikan proses tersebut ke konsep-konsep yang berkaitan. Pada saat siswa-siswa mencapai pemahaman pada level seperti itu, seorang guru dapat kemudian mengekspose mereka ke cara-cara yang lebih efisien untuk mengekspesikan atau melakukan proses-proses yang sama tersebut.

Bergantung hanya pada algoritma-algoritma dan prosedur-prosedur serta berfokus pada jalan-jalan singkat menghasilkan hal dalam efisiensi pengajaran, namun bukan matematika. Langkah-langkah singkat menjadi alat untuk mendapatkan jawaban bersamaan dengan hasil yang tidak diinginkan dari menghindari atau mengabaikan pemahaman konsep, sebuah kompromi atau pertukaran hal yang dapat saja membuat hal tersebut lebih sulit bagi siswa untuk memahami topik-topik yang kompleks sebagaimana mereka akan hadapi pada tingkat selanjutnya di sekolah. Proses dari penyederhanaan sebuah pecahan memberikan sebuah contoh yang sangat baik dari sebuah kegagalan langkah-langkah singkat. Seperti contoh berikut ini:

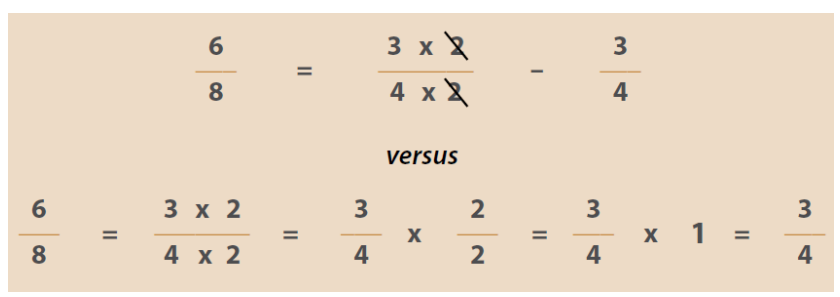

Gambar 1. Kesalahan dalam Penyederhanaan Pecahan

Meskipun efisien, metode pertama dan yang paling ringkas tersebut meninggalkan siswa dengan sebuah pemahaman yang membingungkan dari apa yang sebenarnya terjadi. Berbeda dengan pendekatan singkat pertama, metode yang kedua langkahnya lebih lengkap dan prosesnya meliputi langkah-langkah yang sesuai dan tepat. Dengan menyertakan setiap langkah, proses lengkap tersebut memberikan sebuah pemahaman konsep tentang identitas perkalian, yang ide dasarnya tersebut adalah bilangan apa saja dikalikan dengan 1 maka hasilnya bilangan itu sendiri. Sifat dasar tersebut merupakan sebuah sumber utama yang kuat untuk mendukung dan keyakinan pada sebuah pemahaman yang mendalam tentang apa yang sebenarnya terjadi saat siswa menyederhanakan sebuah pecahan. Lebih penting lagi, 
identitas perkalian tersebut merupakan salah satu dari cara-cara aljabar yang penting dimana digunakan pada penyelesaian persamaan-persamaan. Jika guru menunjukkan begitu saja pada siswa metode yang pertama, siswa hanya belajar bahwa jalan singkat tersebut merupakan cara yang ditampilkan gurunya dan merupakan sesuatu yang mereka diminta untuk melakukannya. Dilain pihak, dengan menekankan dan mengharuskan siswa untuk menggunakan proses lengkap dan menjelaskan apa yang mereka kerjakan, dengan itu guru membantu mereka membentuk sebuah pondasi untuk kemampuan aljabar. Metode yang detail yang menunjukkan semua langkah-langkah kritis membimbing siswa melalui proses tersebut, menghasilkan ke suatu pemahaman yang lebih menyeluruh terhadap apa saja hal dalam penyederhanaan sebuah pecahan yang terlibat dan kenapa hal tersebut berlaku.

3. Hindari angka-angka gundul (naked numbers).

Prase angka-angka gundul (naked numbers) mengarah pada penggunaan yang terlalu sering simbol angka-angka dalam suatu kondisi tertutup, tanpa adanya deskriptor, satuan ataupun konteks. Instruksi tradisional secara seringkali menggunakan angka-angka gundul, khususnya dalam bentuk latihan berulang yang membuat siswa menghafal fakta-fakta atau prosedur-prosedur. Sebagai hasilnya, siswa dengan mudah dapat kehilangan atau tidak dapat melihat makna dari angka-angka serta simbol angka-angka, yang menyebabkan timbulnya sebuah pandangan yang rendah terhadap matematika. Tanpa konteks sama sekali, guru dan siswa sama-sama melupakan makna dari simbol angka-angka serta ide kunci tersebut yang merepresentasikan sesuatu. Dalam melihat pada kemampuan siswa di ujian wajib secara nasional, materi ukuran merupakan salah satu topik dimana siswa secara historis menunjukkan kemampuan yang kurang. Kenapa ini terjadi? Angka-angka gundul merupakan salah satu penyebab utama yang berdiri pada hasil kemampuan yang kurang ini. Ukuran bukan hanya tentang satuan meter ataupun kilogram dan liter. Namun perlu dipandang dan dipahami dari sudut pandang yang lebih luas. Angka 8 bukan hanya simbol dari sebuah bilangan, dan tidak harus selalu berarti 8 meter atau 8 kilogram. Angka 8 dapat merepresentasikan sebuah bilangan tak terbatas untuk konsep-konsep lainnya dari 8 gajah sampai 8 komputer. Oleh karena itu, kita perlu mengoneksikan idea atau gagasan dari ukuran ke pemikiran yang lebih besar tentang representasi dalam matematika. Dimana, siswa dapat mengenali dan memahami bahwa sebuah angka seperti 8 merupakan suatu ekspresi yang tidak lengkap dan sebuah angka tersebut memiliki pengertian lebih dari sebuah kuantitas yang sederhana. Kemampuan rendah siswa dalam rangkaian materi ukuran dapat merupakan sebuah indikasi kekurangan dari sistem penekanan pada bahasa serta representasi 
matematika dan bukan hanya indikasi bahwa siswa memiliki masalah dengan satuan-satuan standar ukuran.

Namun disayangkan, permasalahan yang didiskusikan tersebut tidak muncul dalam kondisi tertutup. Kesalahan-kesalahan tersebut sering muncul secara simultan dan saling memperburuk satu sama lain, membentuk kebingungan siswa dan kesalahan konsep oleh siswa. Perhatikan soal berikut $8 \div 1 / 2$. Pilihan katan yang kurang tetap untuk interpretasi ekspresi soal tersebut adalah “Berapa kali 1/2 dibutuhkan untuk menjadi 8?” Menambahkan pada bahasa yang membingungkan ini instruksional yang tidak lengkap menekankan hanya pada apa yang angka-angka gundul representasikan. Hanya pada apa makna 8 dan 1/2 sebenarnya? Meskipun jika siswa mampu mengelola untuk membuang atau menghilangkan kebingungan tersebut, apakah mereka benar-benar memahami prosedur tersebut? Jika siswa mendapatkan jawaban yang benar, apakah mereka memahami apa yang direpresentasikan jawaban benar tersebut dalam hal ini 16 ?

Dapatkah mereka menerima kenyataan kenapa hasil dari pembagian tersebut "lebih besar" daripada "bilangan aslinya" dan bukannya "lebih kecil"?

Jawaban untuk pertanyaan-pertanyaan tersebut terletak dalam memahami soal yang diberikan dengan penyimbolan dan mengetahui tentang apa yang solusi representasikan.

Dengan mengganti penggunaan kata "dibutuhkan untuk menjadi", bagaimana jika siswa memahami bahwa pertanyaan menjadi "Berapa banyak setengah yang ada dalam 8?" selanjutnya siswa akan memahami bahwa bilangan hasil pembagian tersebut adalah "16 buah setengah", tidak hanya berupa angka gundul 16. Sekarang solusi yang "lebih besar" menjadi masuk akal karena siswa seakan memiliki sebuah 8 sebagai satu kesatuan dan mempartisinya menjadi 16 bagian yang lebih kecil, dalam hal ini setengah.

4. Bantu siswa membuat koneksi antar konsep.

Kita mungkin pernah atau sering mendengar kalimat "kerja cerdas, bukan kerja keras". Hal tersebut menunjukkan bahwa guru-guru diharapkan secara berkelanjutan untuk mengambil lebih dan lebih tanggungjawab. Dalam matematika, satu cara untuk meningkatkan pengajaran dan memaksimalkan waktu instruksional adalah menemukan dan mengaplikasikan koneksi-koneksi antar konsep-konsep matematika dan ide-ide matematika. Sebagaimana telah disebutkan sebelumnya, membuat koneksi-koneksi tersebut merupakan mengambil manfaat dari fakta bahwa pengetahuan tentang sebuah topik meliputi bagian dari 
pengetahuan topik lainnya. Pengetahuan yang telah umum tidak harus diajarkan lagi, namun guru harus mengenali atau mengidentifikasi serta membuat koneksinya. Mengenali koneksikoneksi tersebut tergantung pada pemahaman yang mendalam terhadap konsep-konsep dan proses-proses matematika.

Sebuah contoh dari kesempatan untuk membuat koneksi adalah definisi konseptual dari sebuah rata-rata. Dasar untuk definisi tersebut adalah pemahaman yang mendalam terhadap konsep terkait dari perkalian. Banyak guru mendefinisikan perkalian sebagai penjumlahan berulang, namun dengan pemahaman terbatas itu, langkah menuju ke suatu pemahaman tentang rata-rata sampai pada pemberhentian yang mengagetkan. Memang benar bahwa perkalian merupakan penjumlahan berulang, namun komponen hilang yang penting adalah gagasan atau ide bahwa perkalian merupakan penjumlahan berulang dari grup-grup yang berukuran sama. Ekspresi $3 \times 4$ dapat diuraikan menjadi $4+4+4$, yang merepresentasikan 3 grup yang berukuran sama yang masing-masing 4. Langkah selanjutnya untuk pemahaman yang lebih mendalam terhadap rata-rata adalah membuat sebuah koneksi ke konsep dari pembagian. Review terdekat dari perkalian dan pembagian pada level sekolah dasar dan menengah menunjukkan bahwa proses keduanya melibatkan tiga komponen dasar yang sama yaitu total (jumlah), sebuah bilangan yang menyatakan banyak dari grup, dan sebuah ukuran konstan dari setiap grup. Perkalian dan pembagian sebenarnya lebih cenderung sama dibanding berbeda. Perbedaannya hanya antara dua proses yaitu tentang komponen yang diketahui dan komponen yang yang tidak diketahui. Dengan fokus pada grup-grup yang berukuran sama, siswa melhat dan mengerti bahwa pembagian adalah tentang berbagi yang sama banyak. Dengan pembagian, kita memulai dengan suatu total yang diketahui, sedangkan dalam konteks rata-rata suatu total tidak diketahui. Dengan demikian, perbedaan mendasarnya ada pada titik mulainya. Untuk sebuah rata-rata, kita harus mengkombinasikan grup-grup dengan ukuran berbeda ke dalam suatu total. Setelah itu, kita pada titik mulai dari sebuah konteks pembagian. Dengan menggunakan koneksi ini, siswa menyadari bahwa jika pembagian adalah tentang distribusi yang sama, maka sebuah rata-rata secara sederhana merupakan suatu redistribusi yang sama juga. Biarkan hal tersebut mencair dalam pemahaman siswa. Mendefinisikan sebuah rata-rata sebagai redistribusi yang sama adalah hal yang sederhana, namun dalam dan konseptual, serta dapat diaplikasikan ke banyak konteks; meskipun, suatu definisi konseptual tidak bisa dicapai tanpa sebuah koneksi ke pembagian dan secara berurut, sebuah koneksi ke perkalian yang merupakan dasar pada 
sebuah pemahaman mendalam yang lengkap dari perkalian sebagai sebuah konsep (dan bukan hanya sebatas cara mengalikan).

\section{KESIMPULAN}

Pada pembelajaran bermakna atau meaningful learning lebih menekankan pada keterkaitan materi dengan pengalaman sehari-sehari siswa dan selalu menghubungkan dengan pengetahuan sebelumnya. Pembelajaran bermakna atau meaningful learning dapat dikatakan tercapai bila terwujudnya dua tujuan pembelajaran yang terpenting yaitu untuk membentuk kemampuan retention dan kemampuan transfer. Dalam pengajaran untuk meaningful learning sebaiknya melakukan beberapa hal berikut: menggunakan analogi, menggunakan cerita untuk mendemonstrasikan konsep, menanyakan siswa tentang pengalaman mereka yang berhubungan dengan materi pelajaran, menanyakan ke siswa pertanyaan sedikit lebih tinggi dari apa yang telah diajarkan secara langsung untuk menguji pemahaman mereka. Pada meaningful learning pencapaiannya tidak hanya retention namun juga transfer dan bahkan pencapaian hafalannya (retention) lebih baik daripada rote learning.

Sedangkan pada pembelajaran untuk rote learning lebih menekankan pada hafalanhafalan prosedural yang tidak memerlukan keterhubungannya dengan pengalaman siswa serta tidak mengintegrasikan dengan pengetahuan siswa sebelumnya, serta pada rote learning pencapaiannya hanya retention informasi-informasi baru. Dimana rote learning lebih pada hasil hafalan saja namun tidak sampai pada tahapan penggunaan pengetahuan yang dihafal. Pembelajaran dengan hafalan (rote learning) merupakan aturan atau patokan, dengan sedikit perhatian pada pemahaman terhadapa konsep-konsep matematika. Pembelajaran dengan hafalan bukanlah jawaban dalam matematika, khususnya saat siswa tidak memahami matematika.

Dari uraian mengenai rote learning dan meaningful learning tersebut menunjukan bahwa seorang pengajar berperan penting dalam membentuk hasil belajar siswanya. Perbedaan mendasar dari kedua tipe belajar tersebut adalah pada upaya dan proses kognitif yang dilakukan oleh siswa. Siswa menunjukkan atau mendemonstrasikan pemahaman konsep dalam matematika saat mereka memberikan bukti (provide evidence) bahwa mereka dapat: mengenali (recognize), menandai (label), dan menghasilkan atau memberikan (generate) contoh-contoh dari konsep-konsep; menggunakan (use) dan menghubungkan 
(interrelate) model-model, diagram-diagram, manipulasi-manipulasi, dan representasirepresentasi beragam dari konsep-konsep; mengidentifikasi (identify) dan mengaplikasikan (apply) prinsip-prinsip; mengetahui (know) dan mengaplikasi (apply) fakta-fakta dan definisi-definisi; membandingkan (compare), membedakan (contrast), dan mengintergasikan (integrate) konsep-konsep dan prinsip-prinsip yang berkaitan; mengenali (recognize), mengintepretasi (interpret), dan mengaplikasikan (apply) tanda-tanda, simbol-simbol, istilah-istilah (terms) yang digunakan untuk merepresentasikan konsep-konsep.

Pemahaman konsep (CU) memanifestasikan atau merefleksikan (reflects) suatu kemampuan siswa untuk memberikan penjelasan serta alasan (to reason) dalam konteks atau situasi (in-settings) yang melibatkan pengaplikasian yang hati-hati dan terukur dari definisidefinisi konsep, relasi-relasi, atau representasi-representasinya. Pembelajaran dengan pemahaman merupakan hal yang mendasar dan penting (essential) untuk membuat siswa mampu untuk menyelesaikan bentuk-bentuk baru permasalahan-permasalahan yang mereka akan hadapi secara kebutuhan di masa depan.

Guru-guru matematika harus menciptakan kesempatan-kesempatan (opportunities) bagi siswa untuk mengomunikasikan topik-topik pemahaman konsep mereka. Hal ini dapat melibatkan struktur-struktur instruksi pembelajaran yang membutuhkan sebuah perubahan dalam teknik-teknik pengajaran (pedagogical techniques). Ide-ide atau gagasan-gagasan untuk mendukung siswa dalam membangun pemahaman konsep (CU) matematika siswa haruslah ditunjang sumber daya bagi guru-guru.

Pengajaran Matematika secara konsep menurut Molina sebaiknya melakukan hal-hal berikut. Gunakan bahasa instruksional secara hati-hati. Tekankan pengajaran pada konsep dibandingkan algoritma dan jalan-jalan singkat. Hindari angka-angka yang gundul (naked number). Bantu siswa membuat koneksi antar konsep. Dengan menghindari langkah-langkah singkat yang merupakan suatu komponen umum dari instruksi matematika dan tidak fokus pada bahasa instruksional serta pemahaman mendalam terhadap konsep-konsep matematika, guru dapat membantu siswa mereka membangun ketrampilan matematika yang dibutuhkan untuk perubahan serta inovasi dalam area STEM. Oleh karena itu, seorang pengajar perlu mempertimbangkan strategi pembelajaran yang tepat agar tercipta efektifitas belajar dan siswa mencapai dua kemampuan tersebut. 


\section{REFERENSI}

Korb, K.A. (2011). Meaningful Learning. University of Jos.

Mayer, R.E. (2002). Theory into Practice. Volume 41, Number 4, Autumn. College of Education, The Ohio State University.

Mayer, R.E., \& Witrock, M.C. (1996). Problem Solving Transfer. Handbook of Educational Psycology. New York: Macmillan.

Molina, C. (2014). Teaching mathematics conceptually. SEDL insights, 1(4), 1-8

National Center for Education Statistics. (2003). Mathematical Abilities, (Online), (nces.ed.gov/nationsreportcard/mathematics/abilities.asp)

National Center for Education Statistics. (2013). The nation's report card: A first look: 2013 mathematics and reading. NCES 2014-451.

National Council of Teachers of Mathematics. (2000). Principles and Standards for School Mathematics. Reston, VA: NCTM.

National Research Council. (2001). Adding It Up: Helping Children Learn Mathematics. Washington, DC: National Academy Press. 
